\title{
The Effectiveness of Zakat Payment Technology
}

\author{
Rina Nurhayati ${ }^{1}$, Febby Aulia Purwadinata ${ }^{2}$, Ahmad Saepudin $^{3}$ \\ \{rinanurhayati@sties-purwakarta.ac.id ${ }^{1}$ \} \\ STIE Syari'ah Indonesia, Purwakarta, Indonesia ${ }^{1,2,3}$
}

\begin{abstract}
This study discusses to answer the question of overpayment and payment of zakat with the application system at National Amil Zakat Institution (BAZNAS) Subang Regency and how to use the application in the payment of zakat at National Amil Zakat Institution (BAZNAS) Subang Regency. The research objective was to determine the role of application technology in payment of zakat. This study uses a qualitative descriptive method using a case study approach, by exploring primary and secondary data from interviews, observations and library research. The results of the study found that in the practice of paying zakat for Muslims using the application at BAZNAS Subang district is very effective for users who are busy with their daily activities. There are several advantages and disadvantages in it for the advantages can make it easier for people who are quite busy everyday, speeding up the payment process compared to the manual way and the performance of amil zakat to be more professional.
\end{abstract}

Keywords: Application technology, payment of zakat, BAZNAS Subang

\section{Introduction}

The use of computers and the internet as a tool in completing work is increasingly in demand by various groups, both as data managers or special processes in daily life, because they have a high level of accuracy and fast work processes. Using a special application will make it easier to solve problems. Along with advances in computer and internet technology, it is appropriate if the science of fiqh, especially that which discusses zakat payments, also develops, followed by technological developments, then the delivery of information about fiqh, especially zakat information online, will be easily accessible to the public. According to information in the Al-Qur'an that all the prophets and messengers have the teachings of zakat in accordance with the findings of new human technology in managing their life patterns. The concept of zakat technology as a purification of body and soul was discovered by the Prophet. As a prophet enlightening the earth and enlightening the mind of man.

Information about zakat is still difficult to obtain because it still depends on someone who understands zakat, if that person is not available or difficult to find information will be difficult to obtain, to make it easy for users to access information about zakat without the need to come directly to people the person concerned will save more time and the user can know immediately how much money must be spent to pay zakat mal or the assets he owns. Low awareness of zakat in the perspective of Antonio Syafi'i can open up space with humanitarian conflicts, because zakat is maaliyah ijtima'iyyah (worship related to the social economy) and it needs supporting technology in managing the Zakat Information System Management (ZISM). 
The majority of Indonesia's population is Muslim, zakat should be able to help a little in terms of poverty alleviation that exists today. And it is not only potential in terms of zakat collection, but there must be improvements in terms of zakat management at this time, and this will affect the distribution of zakat if zakat management is fairly good. In terms of management, there should be support from several groups, both from the government and from the community. The management of zakat has been legalized by the state in 1999. With evidence of the existence of Law No. 38/1999 on Zakat Management. Then it was updated in 2011, namely Law No. 23/2011. It is explained in the law that zakat management is carried out by two existing institutions, namely BAZ and LAZ. These two institutions have an important role in terms of zakat management, which distinguishes between the two, namely if BAZ is formed by the government directly, while LAZ is formed by the community or community association, which has the same goal of making management run well and in accordance with the rules and in accordance with sharia. These institutions have the same activities in accordance with the Law, which include planning, collection, distribution and utilization activities.

This condition illustrates that information technology is needed as a supporting facility in zakat services to organize the zakat information management system. The importance of information technology as a supporting medium that can facilitate BAZNAS in the collection, management and distribution of zakat effectively for the community. When BAZNAS has not been able to use Zakat Information Technology as a strength and a tool in managing the ZIS Administration system, it can be predicted that ZIS has not been able to become a good economic regulation for the community. Information technology has become an indicator of a nation's progress, the weaker the technological facilities used, the lower the competitiveness of a society.

Along with the development of the times and the development of technology, this has become a common thing that amil zakat institutions do. With the use of technology that almost all people understand, one of the BAZNAS institutions issued an online application for zakat payments. This is an innovation that is tailored to the current developments.

In this modern era, it is developing very rapidly in terms of education, economy, social and culture and the most visible influence is in technology and communication issues. Development of communication and information in its distribution is very fast, and this affects the order of people's lives in at this time. The spread of this communication can penetrate any circle and anyone for those who are able to access technological and communication developments. Current technological progress is indeed very fast and fast, and following the flow of these developments, every institution in Indonesia should make adjustments so as not to be left behind in terms of information and in terms of technology.

The very fast flow of information demands an adequate line of information. This results in the development of communication technology that can be easily understood by the community. Basically, the economic flow that will determine the dynamics of human life today and humans will follow the flow of these dynamics. The most extensive media network today is the internet, which almost everyone can easily access. This network can easily innovate and develop according to the development of society at this time, and almost all human needs are connected to the internet. The internet can be said to be a medium that is used most needed at this point.

One of the things that is utilized by the development of this technology is the creation of several online systems, both in terms of online shopping and in other matters, such as online zakat payments in the case that BAZNAS creates an online zakat payment application. This innovation is a use because of the development of technology. information and easy internet access. 
Because basically a technology is a producer of culture, which means that it greatly affects humans in terms of thoughts, actions and emotions. According to Domicik, the impact of information technology on knowledge is about people's perceptions and attitudes, mass media, especially television and the internet, become agents of socialization or spread values and have an effect on values, perceptions and beliefs. Because it has an influence, the creation of a new innovation in terms of technology will be able to have an influence on anyone who understands this technology, because in this day and age humans choose to live practically, for example in terms of shopping with the development of technology, today they choose online shopping. This is BAZNAS capturing this phenomenon by creating an online zakat payment application system.

The context of ZIS is closely related to the condition of the nation which has not yet fully risen from its downturn due to the weak system of zakat technology which has an impact on the economic, social and political crisis of Muslims who do not have zakat technology which is mandated by the law on public services. So, based on the main problem, the objectives of the research are (1) to find out the excess in paying zakat using the online system at BAZNAS, Subang Regency, (2) to find out the shortcomings in the payment of zakat by using the online system BAZNAS, Subang Regency, and (3) to find out the procedure for paying zakat using the online system BAZNAS, Subangi Regency. This research is expected to provide useful information about the role of technology in paying Zakat.

\section{Method}

Sugiyono explained that the research method is basically a scientific way to obtain data with specific purposes and uses. Based on this, there are four key words that need to be considered, namely, scientific method, data purposes and uses. The scientific way means that research activities are based on scientific characteristics, namely rational, empirical and systemic. Rational means that research activities are carried out in ways that make sense so that human reasoning can reach them. Empirical means that the ways that are done can be observed by the human senses, so that other people can observe and know the methods used. Systemic means that the process used in the research uses certain logical steps.

One of the most important elements in research methodology is the use of certain scientific methods that are used as a means to identify the size of the object or symptom and seek solutions to the problem being studied, so that the results obtained can be scientifically accounted for. So it can be concluded that the Research Methodology is a set of rules, activities and procedures used by actors of a scientific discipline. In this research methodology, there are 2 (two) types of data, namely: (1) qualitative data, namely data expressed in the form of words, sentences and pictures, and (2) quantitative data, namely data expressed in numerical form or extrapolated qualitative data.

The process of compiling this thesis, the research methodology used is a qualitative type, namely a method that analyzes data in the form of words. This method is also called an artistic method because the research process is more of an artistic nature and is called an interpretive method because the research data is more concerned with the interpretation of the data presented in the field. Research is conducted on natural objects, natural objects are objects that develop as they are and are not manipulated by researchers and the presence of researchers does not affect the dynamics of these objects. To get a broader and deeper understanding of the social situation under study, the data collection technique is triangulation, which is to use various combined 
data collection techniques. Data analysis is inductive based on facts found in the field and then constructed into theory. Qualitative methods are used to obtain in-depth data, data that contains meaning. Meaning is actual data, definite data is a value behind the visible data. Therefore in qualitative research it does not emphasize generrelation but rather emphasizes meaning.

Data collection techniques are the methods used for data collection. The data required in this writing is quite diverse, which cannot be collected by a data collection technique. Determination of Informants, an informant is a person who is used to provide information about the situation and conditions of the research background, so he must have a lot of experience in the research background and must volunteer to become an informant or a member of the research team even though it is only informal. The technique used by researchers to obtain informants is purposive sampling technique. Purposive Sampling is determining the subject / object according to the goal. Researching with qualitative research usually has a designated place to go. By using personal considerations in accordance with the research topic, research selects the subject / object as the unit of analysis.

The researcher chooses the unit of analysis based on his needs and considers that the unit of analysis is representative. The following are the criteria for informants determined in this study: (1) managers and administrators of BAZNAS Subang, Chairman, Treasurer, and (2) community of application users. The location of the research that the researchers conducted was in the amil zakat agency, Subang Regency, where the Baznas had the application of zakat payments using an application that would be researched by researchers. Sources and Data Collection Techniques are (1) primary data, is data that is collected and processed by an organization or individual directly from its object. The data collection was carried out specifically to solve the research problem being studied, and (2) secondary data, is data obtained in a ready-made form, which has been collected and processed by other parties, usually in the form of publications. This kind of data has been collected by other parties for specific purposes which are not for the specific purposes of the research currently being carried out by the researcher.

Data Analysis Techniques (1) observation, observation method is observation and recording with systematics of the phenomena being investigated. Nasution stated that observation is the basis of all science, scientists can only work based on data, namely facts about the real world obtained by observation, (2) interview, the interview is one of the methods in collecting data by way of communication, namely through contact or personal relationships between interviewer and informants. In the interview that is carried out are: "a conversation with a specific purpose, the conversation is carried out by two parties, namely the interviewer who asks the question and the interviewee who provides answers to the question.

\section{Results and Discussion}

History of BAZNAS Subang Regency, in 2006, it was a transition period after going to the previous vacancies and also changing the name from BAZIS to BAZDA. This is an adjustment to Law no. 38 of 1999 concerning Zakat Management, as well as Regional Regulation No. 2 of 2006 concerning Zakat Management in Subang Regency; 1. Period 2006 - 2009. In the 2006 2009 period chaired by $\mathrm{H}$. Ahmad Hanafi, BE was a period of improving infrastructure such as providing professional human resources through open selection of candidates for BAZDA management, procurement of adequate office facilities and infrastructure so that in this period BAZNAS (at that time BAZDA) Subang Regency had new management results. adequate 
selection and building, facilities and infrastructure through assistance from the Regional Government of Subang Regency. 2. Period 2009 - 2014. In this period, chaired by KH. Moh. Musa, M.Si., was the program planning and implementation period. This period includes compiling and implementing programs that are consumptive in nature, but also for productive and creative purposes. There are quite a lot of outreach activities carried out directly or indirectly in every sub-district, agency / agency, businessmen and schools. As in the previous period, this period saw a transition period for adjusting the name from BAZDA to BAZNAS considering the issuance of Law No. 23 of 2011 concerning the new Zakat Management. Programs and activities began to run from the collection, utilization and distribution, BIS HEAVEN, SUBANG GIRL, DIM and professional zakat among civil servants began to grow and run with the support of sufficient BOP from the Regional Government of Subang Regency, 3. Period 2014 - present. The management and implementation of BAZNAS in Subang Regency in this period was confirmed on January 20, 2015 by the Regent of Subang with the Chairperson Drs. H. Anang Jauharuddin, M.Pd., so that at the beginning of his management year it is necessary to adjust the work procedures, implementation and duties of each field. This happened because of a significant change in institutional structure, for example regarding the number of BAZNAS leaders in Subang Regency consisting of 4 (4) deputy heads of fields / sections and 1 (one) chairman, who are assisted by secretarial executors and UPZ at every level, institution and agency. This period succeeded in developing programs and activities that had been centralized into decentralization and involving all components of society as well as touching all levels of society, especially the mustahik in the regions. Creative and innovative activities also color BAZNAS's current journey. Homecoming Post, scholarships, title ta'jil and sahur with mustahik, donations for orphans, clean water assistance, natural disaster relief and completion of the new BAZNAS building. The data collection for muzakki and mustahik, infaq haji and professional zakat continues to grow and develop.

Zakat Payment Procedure Using the Application System at Baznas Subang Regency. The facilities offered by ABAZNAS which are online based include online zakat internet, mobile zakat, card-zakat and Zakat applications.

Online Internet Zakat, through online internet services, services that can be used include online zakat payments through the Baznas website or through online zakat services from the muzakki bank account website. Another service used is the online payment of zakat through an ATM. Muzakki can use the e-zakat menu in the ATM menu to pay zakat. Furthermore, zakat payments via transfer of funds from mobile zakat counters or from zakat corners are available in various strategic places such as shopping centers or offices.

Mobile Zakat. With cellular phone facilities, zakat can be paid through the mobile-zakat menu, which is a menu that has been provided in every cellular service, so that when muzakki intends to pay zakat, just open the menu on his cell phone. For sms-zakat, the concept is the same as for the zakat mobile menu. The difference is that sms-zakat is done manually. Muzakki sends an SMS containing the muzakki name, muzakki account and the amount of zakat paid to the zakat services number Baznas

Card Zakat. With this facility muzakki can pay zakat through their debit / credit cards. Internet zakat, mobile. The payment system in online internet zakat, mobile-zakat and zakat card is a transfer of funds from the muzakki account to Baznas. Information sent by muzakki via e-zakat. Furthermore, the funds in the muzakki account will automatically be debited by the bank if the muzakki makes payments through the e-zakat facility. The funds are then transferred to the Baznas account.

Procedures for using the application; 1. Open Playstore / iOS on your handphone then download install the application, 2. Then after opening the login / login application using e-mail 
/ facebook / nik, 3. Then enter the zakat page in which there are several menu options and select the zakat menu, 4. Next enter the zakat calculator menu, 5. Enter the nominal to be zakat. can pay through several banks in Indonesia, 6 . The final step is transfer according to the nominal to be zakat, 7. Wait until the process is complete.

In the results of the interview that the author researched in the field with Mr. Mugni as the chairman of the Subang District Baznas, he stated that the advantages of this zakat application are:

a. Provides convenience and is very helpful in paying zakat compared to manual payments and manual payments at the Baznas office.

b. Make zakat closer to the community, because the zakat payment system now uses a system that is easy and commonly used by the community.

c. The performance of amil zakat, looks more professional. The level of public trust in the performance of amil becomes higher.

d. Baznas branches and zakat mobile counter can now be connected in one online network. Apart from the advantages of the zakat application, there are also several disadvantages in it, namely:

a. There are still no special operators who hold this part of the zakat application,

b. Because the zakat application uses high-level technology, it certainly requires a lot of money to build a perfect network,

c. Online internet zakat utilizes internet facilities in it. Please note that cybercrime crimes have occurred a lot on the internet, for example, such as carding, hacking, cracking, phishing, defacing, spamming and malware.

From the application we can calculate zakat, even more sophisticated cellphones can be used to make a zakat calculator as a tool to calculate assets and clean it by issuing infak and shodaqoh as a cleanser for the human body and soul to be healthy in thinking, communicating and behaving.

\section{Conclusion}

In conclusion, the zakat application technology makes it easy for Muslims to pay their zakat. Zakat payers do not need to mobilize to the place of payment, but simply do it through the zakat application. The role of the zakat application is of course very helpful for the community in making transactions. It's just that sometimes there is a feeling of reluctance to pay zakat which is influenced by various internal and internal factors of zakat payers. However, socialization is also needed that can influence Muslims to pay zakat through the application, so that Baznas will easily report openly on the amount of zakat income every month, semester or yearly.

As with the results and discussion of research on the role of application technology in paying zakat invites people to pay zakat through the application. Researchers suggest the need to recruit employees who have backgrounds or professions related to applications and communications. In order to increasingly trust the public, especially prospective zakat distributors, researchers suggest the BAZNAS Kab. Subang needs to publish to the mass media, one of which is print media, namely reports on activities of association, management, and distribution of zakat funds from muzakki circles so that the public knows more about where their zakat will be managed and distributed. To disseminate information about the zakat 
payment application, researchers suggest that the BAZNAS Subang Regency socialize more to the community.

\section{References}

[1] Achmad Faisal, Zakat Praktis, (Jakarta, Pustaka Sinar Harapan, 2015)

[2] Budi Sutedjo Dharma Oetomo, Pengantar Teknologi Informasi Internet, (Yogyakarta, Penerbit Andi, 2007)

[3] Elsa Kartika Sari, Pengantar Hukum Zakat dan Wakaf, (Jakarta, PT. Grasindo, 2006)

[4] Fahrur Mu'is, Zakat A-Z Panduan Mudah, Lengkap, dan Praktis tentang Zakat, (Solo, Tinta Medina, cet. 1)

[5] Heri Wahyudi. Aplikasi Penghitung Jumlah Zakat Yang Dibayar Berbasis WEB dalam http:// etheses.uin palembang.ac.id/2287/6/11520008_Bab_2.pdf diakses 1 Mei 2018 jam 20.00 WIB.

[6] Juliansyah Noor, Metodologi Penelitian Skripsi, Tesis, Disertasi dan Karya Ilmiah (Jakarta, Prenada media Group, 2011)

[7] Rusman dkk, Pembelajaran Berbasis Teknologi Informasi dan Komunikasi. (Jakarta, Grafindo persada, 2012)

[8] Syarifudin, "Pemanfaatan Teknologi ZIS" dalam http://www.slideshare.net/html. Diakses tanggal 30 April 2018 